\title{
Avaliação microbiológica das águas dos bebedouros do Campus I da Faculdade de Medicina do Triângulo Mineiro, em relação à presença de coliformes totais e fecais
}

\author{
Microbiological evaluation of water from drinking-fountains at Campus I \\ of Faculdade de Medicina do Triângulo Mineiro by the \\ presence of total and fecal coliforms
}

\author{
Ana Carolina Santana de Oliveira ${ }^{1}$ e Ana Paula Sarreta Terra ${ }^{2}$
}

Senhor Editor:

A saúde pública requer água potável segura, o que significa que ela deve estar livre de bactérias patogênicas. Entre os patógenos disseminados em fontes de água, os patógenos entéricos são os mais freqüentemente encontrados. Como conseqüência, fontes de contaminação fecal em água devido à atividade humana devem ser estritamente controladas ${ }^{35}$. Este controle é feito medindo-se alguns parâmetros como presença e níveis de coliformes fecais e totais. 0 uso do grupo coliforme como um indicador de possível presença de patógenos entéricos em sistemas aquáticos tem sido sujeito de debates por muitos anos. Muitos autores reportam surtos de doenças ligadas à água em casos de variação dos coliformes ${ }^{10}$.

0 grupo coliforme inclui uma grande diversidade em termos de gênero e espécie, principalmente aquelas pertencentes à família Enterobacteriacae. Os membros do grupo coliforme são descritos como:

1. todos aeróbicos e anaeróbicos facultativos, Gramnegativos, não formadores de esporos, bastonetes que fermentam lactose com formação de gás e ácido em $48 \mathrm{~h}$ a $35^{\circ} \mathrm{C}$ ( técnica dos tubos múltiplos) ${ }^{79}$.

No Brasil, as normas são definidas pela portaria 1469 de 29/12/2000 (2/01/2001) - Ministério da Saúde, capítulo IVPadrão de potabilidade ${ }^{26}$. Estas definem que água para consumo humano deve ser livre de Escherichia coli ou coliformes termotolerantes com ausência em 100ml ou positividade de até $5 \%$ para coliformes totais.

A avaliação da presença de coliformes totais e fecais foi realizada através da utilização de amostras de água dos bebedouros do Campus I desta Faculdade A pesquisa de coliformes totais realizou-se mediante a técnica dos tubos múltiplos ${ }^{34}$. Todos os tubos com reação presuntiva positiva são subseqüentemente sujeitas a teste confirmatório em Caldo Verde Brilhante Lactose Bile e Caldo Escherichia coli ${ }^{1511}$.

Os resultados mostraram que todos os bebedouros apresentaram de certa forma ou em algum momento, algum tipo de contaminação. Todos eles apresentaram reação presuntiva positiva tanto pelas análises pré-bebedouro quanto pelas análises pós- bebedouros. Esta ocorrência em fontes de água tratada é a mais comum causa de violação dos padrões de potabilidade. Tradicionalmente, a presença de bactéria coliforme em água potável tem sido vista como um indicador de contaminação fecal intimamente ligado a tratamento inadequado ou inabilidade em manter desinfecção residual em água tratada ${ }^{14}$.

Os bebedouros que apresentaram menor contaminação foram aqueles abastecidos de água diretamente da rua, ou seja, água que não passou por um dos grandes reservatórios existentes no prédio da Faculdade. Esta é uma característica operacional no sistema de distribuição fortemente associada com 0 aumento das taxas de ocorrência de coliformes. Reservatórios ou tanques de estocagem no sistema de distribuição são necessários para prover pressão adequada e reserva de água. Entretanto, esses tanques podem ser locais onde a água estagna, os resíduos de desinfecção se dissipam e a qualidade microbiológica se deteriora pela criação de um biofilme de bactérias em algum ponto crítico desta distribuição ${ }^{48}$.

Outro fator que contribuiu para a positividade de coliformes foi o material do qual são constituídas as

1. Faculdade de Medicina do Triângulo Mineiro, Uberaba, MG. 2. Departamento de Microbiologia da Faculdade de Medicina do Triângulo Mineiro, Uberaba, MG. Endereço para correspondência: Dra. Ana Paula Sarreta Terra. Depto de Microbiologia/FMTM. Pça Manoel Terra s/n, Centro, 38015-050 Uberaba, MG. e-mail: csarreta@ terra.com.

Recebido para publicação em 18/11/2003

Aceito em 19/4/2004 
tubulações que distribuem a água. Estas são constituídas de ferro, material muito utilizado quando da construção do prédio há mais de cinquenta anos. A corrosão de encanamentos de ferro podem produzir protuberâncias as quais aumentam a área de superfície da tubulação, aumentando 0 transporte de nutrientes para a superfície, precipitando compostos orgânicos e promovendo rachaduras que protegem as bactérias da desinfecção $0^{4}$.

Inúmeros outros fatores poderiam ter auxiliado num melhor diagnóstico da situação da água para consumo discente nesta Faculdade. Entretanto, o objetivo por nós pretendido foi alcançado, esperando que medidas apropriadas sejam tomadas para que a qualidade da água que nossos alunos consomem seja aquela a mais adequada possível.

\section{REFERÊNCIAS BIBLIOGRÁFICAS}

1. Azerêdo G. Caracterização das águas dos bebedouros do Campus I Universidade Federal da Paraíba, sob o ponto de vista microbiológico. Revista Higiene Alimentar 15: 79-82, 2001.

2. Conselho Nacional do Meio Ambiente (CONAMA). Resolução nํ 20, 18 de junho de 1986, Ministério do Meio Ambiente, Brasília, 1986.
3. Edberg SC, Edberg MM. A defined substrate technology for the enumeration of microbial indicators of environmental pollution. Applied and Environmental Microbiology 54: 1595-1601, 1988.

4. Le Chevallier MW, Welch MJ, Smith DB. Full-Scale Studies of Factors Related to Coliform Regrowth in Drinking Water. Applied and Environmental Microbiology 54: 2201-2211, 1996.

5. LeClerc H, Mossel DAA, Edberg SC, Struijk CB. Advances in the bacteriology of the coliform group: their suitability as markers of microbial water safety. Annual Review of Microbiology 55: 201-234, 2001.

6. Ministério da Saúde. Portaria no1469, Brasília, 2000.

7. Rompré A, Servais P, Baudart J, de-Roubin MR, Laurent P. Detection and enumeration of coliforms in drinking water: current methods and emerging. Journal of Microbiological Methods 49: 31-54 2002.

8. Silva Jr EA . Manual de Controle Higiênico - Sanitário em Alimentos.4 $4^{\text {a }}$ edição. Livraria Varela, São Paulo, 2001.

9. United States Enviromental Protection Agency. Total coliform rule and surface water treatment rules. Federal Regulations. Government Printing Office, Washington, DC, 1990.

10. Van Netten C, Pereira R, Brands R. Drinking Water supply and management practices in British Columbia, 1997-1998. Canadian Journal of Public Health 93: 14-18, 2002.

11. Weyandt RG. The role of modern biochemical methods in the determination of hygienically relevant microorganisms in foodstuff and (drinking) water. Analytical and Bioanalytical Chemistry 372: 230-231, 2002. 